\title{
Fine root density and root biomass of two Douglas-fir stands on sandy soils in the Netherlands. 2. Periodicity of fine root growth and estimation of belowground carbon allocation
}

\author{
A. F. M. OLSTHOORN ${ }^{1 *} \&$ A. TIKTAK ${ }^{2 * *}$ \\ ${ }^{1}$ Department of Forestry, Wageningen Agricultural University, P.O. Box 342, NL 6700 AH \\ Wageningen, Netherlands (* Present address: 'De Dorschkamp' Research Institute for For- \\ estry and Urban Ecology, P.O. Box 23, NL 6700 AA Wageningen, Netherlands) \\ ${ }^{2}$ Laboratory of Physical Geography and Soil Science, University of Amsterdam, Dapper- \\ straat 115, NL 1093 BS Amsterdam, Netherlands ( ${ }^{* *}$ Present address: Institute for Public \\ Health and Environmental Protection, P.O. Box 1, NL 3720 BA Bilthoven, Netherlands)
}

Received 16 November 1990; accepted 19 December 1990

\begin{abstract}
Detailed studies on the periodicity of fine root growth were carried out in the two Douglas-fir stands of the Dutch ACIFORN project over a two-year period. The perforon method allows the direct, in situ observation of root tips growing in long horizontal tubular channels in the soil. The number of white root tips was used as an indication of periodicity of fine root growth. In the first year the number of white root tips peaked just before budbreak, and then declined gradually towards autumn. Despite a fairly high soil temperature in the winter, few white root tips developed between October and April. In both stands, most of the fine roots died during the dry spring of the second year. There is some evidence that many fine roots died at bulk soil water pressure heads of around $-0.08 \mathrm{MPa}$. Due to dry periods in the second year of observation, the periodicity of fine root growth showed a different pattern, especially in the stand with lower water holding capacity in the soil. Based on certain assumptions, the belowground carbon allocation in both stands was estimated from the biomass of fine and coarse roots. In the less productive stand more carbon per surface area is allocated to the fine roots than in the more productive stand, but the carbon allocation to the coarse roots is greater in the more productive stand. The effect of recent nitrogen deposition from the atmosphere on belowground carbon allocation is discussed briefly.
\end{abstract}

Keywords: atmospheric nitrogen deposition, belowground carbon allocation, fine root periodicity, mortality, pressure heads, Pseudotsuga menziesii, soil water potential, turnover of fine roots, water relations

\section{Introduction}

The periodicity of tree root growth is understood less well than the periodicity of aboveground growth. Since the total amount of carbon allocated to the root system largely depends on the growth of fine roots (McClaugherty et al., 1982; Linder \& 
Axelsson, 1982), data on fine root biomass, including information on death and replacement, are essential to be able to estimate of the amount of assimilates necessary for belowground growth. In an earlier paper, Olsthoorn (1991) presented data on fine root density and root biomass in two Douglas-fir plantations of the ACIFORN project (ACIdification of FORests in the Netherlands) on sites of different quality in the Netherlands over three consecutive years.

The 'average turnover' of fine roots per year can be defined as the quotient of the mean annual fine root biomass divided by the annual fine root production. Santantonio \& Hermann (1985) used this as a definition of 'turnover rate'. In the ACIFORN stands, only the fine root biomass in the early summer in three consecutive years is known (Olsthoorn, 1991). Both Santantonio \& Hermann (1985) and Kurz \& Kimmins (1987a) found that in early summer the fine root biomass in the stands they studied in the Pacific Northwest of America was much larger than the yearly mean. Kurz \& Kimmins found the annual fine root production to be equal to the fine root biomass in May. Considering the differences in definition, this is in agreement with the findings of Santantonio \& Hermann (1985).

In the present study, use was made of the fine root biomass in early summer, together with data on coarse roots, to estimate the total belowground carbon allocation in the two stands. With some assumptions, the total yearly carbon allocation (in tons of carbohydrates per hectare per year) to the root system of trees can be expressed as:

$$
C_{\mathrm{b}}=\left(W_{\mathrm{fr}} \times M_{\mathrm{fr}}+P_{\mathrm{fr}} / G\right)+\left(W_{\mathrm{cr}} \times M_{\mathrm{cr}}+P_{\mathrm{cr}} / G\right)
$$

where:

$C_{\mathrm{b}}=$ belowground carbon allocation ( $\left.\mathrm{t} \mathrm{CH}_{2} \mathrm{O} \mathrm{ha}^{-1} \mathrm{yr}^{-1}\right)$

$W_{\mathrm{fr}}=$ weight of fine roots $\left(\mathrm{t} \mathrm{ha}^{-1}\right)$

$M_{\mathrm{fr}}=$ maintenance respiration fine roots $\left(\mathrm{t}_{2} \mathrm{O} \mathrm{t}^{-1} \mathrm{yr}^{-1}\right)$

$P_{\mathrm{fr}}=$ production of fine roots $\left(\mathrm{t} \mathrm{ha}^{-1} \mathrm{yr}^{-1}\right)$

$G=$ growth efficiency $\left(\mathrm{t} \mathrm{t}^{-1} \mathrm{CH}_{2} \mathrm{O}\right)$

$W_{\text {cr }}=$ weight of coarse roots $\left(\mathrm{tha}^{-1}\right)$

$M_{\mathrm{cr}}=$ maintenance respiration coarse roots $\left(\mathrm{t} \mathrm{CH}_{2} \mathrm{O} \mathrm{t}^{-1} \mathrm{yr}^{-1}\right)$

$P_{\mathrm{cr}}=$ production of coarse roots $\left(\mathrm{t} \mathrm{ha}^{-1} \mathrm{yr}^{-1}\right)$

As the soil fertility of these stands is different, the results of these calculations could be indicative of the effects of increased nitrogen supply due to recent atmospheric input on the total belowground allocation of carbon and on fine root densities in forested areas and could partly explain the reported nutrient imbalances in European forests as a result of nitrogen saturation (Mohren et al., 1986; Hüttl, 1990; Kazda, 1990; van den Burg, 1990). The present paper deals with the periodicity of fine root growth in relation to weather and soil moisture conditions in the same stands to be able to make an estimate of the belowground carbon allocation per year. 


\section{Methods}

\section{Field measurements}

The studies on periodicity of root growth were carried out in two fully stocked, fast growing Douglas-fir plantations of the ACIFORN project, which were used to study the influence of air pollution on forest growth (Evers et al., 1987). For a description of sites and stands see Olsthoorn (1991).

Use was made of the Perforon method (or perforated soil system), originally developed by van den Tweel \& Schalk (1981) and Bosch (1984) for greenhouse trials, to study the periodicity of root growth of Douglas-fir. Roots inside the tubular channels made by this method behave as if encountering natural open spaces or cracks in the soil (Whiteley \& Dexter, 1984) and can be observed.

In each stand, three dominant or co-dominant trees were selected for the root studies. Details of the perforon root cellar are given in Figure 1. A pit was dug $1.3 \mathrm{~m}$ away from the stem. A $3 \mathrm{~mm}$ thick stainless steel plate, with perforations $14 \mathrm{~mm}$ in diameter, was positioned at the wall closest to the tree. The perforations in the steel plate were arranged in 23 horizontal rows and 36 alternating vertical columns. The other walls were covered with insulated boards to support the soil and to hold the steel plate exactly in position. The pit was covered when no observations were being made.

In March 1987, horizontal tubular channels $12 \mathrm{~mm}$ in diameter and $32 \mathrm{~cm}$ long were made by inserting a small corer through the perforations in the steel plate, in a $15 \mathrm{~cm}$ vertical zone, and removing the soil cores. In sandy material the channels remained open for over three years, even during periods of severe frost or drought. After the initial disturbance the roots were able to grow freely within and across the channels. Observations on root tips were made with a small medical endoscope $4 \mathrm{~mm}$ in diameter and $30 \mathrm{~cm}$ long (uroscope), mounted on a small CCD camera with a camera support. The images of the roots were displayed on a TV screen. At the end of the 1987 growing season a balance was achieved between the number of new roots growing into the channels and the number of roots growing across the channels back into the soil. In this paper only the data on numbers of root tips in 1988 and 1989 are presented. In the tree perforon root cellars per site, the total length of the observation channels was $53 \mathrm{~m}$.

Root tips inside the channels were observed monthly so that the current activity of the roots could be recorded. Mycorrhizal root tips could be distinguished from non-mycorrhizal brown root tips by colour or structure of the fungal mantle at the root tips (Figure 1c). Living root tips were classified as mycorrhizal, brown or white. Mycorrhiza were recorded separately, because the periodicity of the growth of the mycorrhizal root tips was difficult to see since there were only minor changes in colour during active growth. Non-mycorrhizal roots were considered to be actively growing when the root tips were white (Krueger \& Trappe, 1967). Root tips that were black, shrivelled or mouldy were considered dead and were not counted.

The monthly increase in stem diameter during the growing season was measured with permanent increment bands (PVC) on the trees being monitored by the perforon system. 


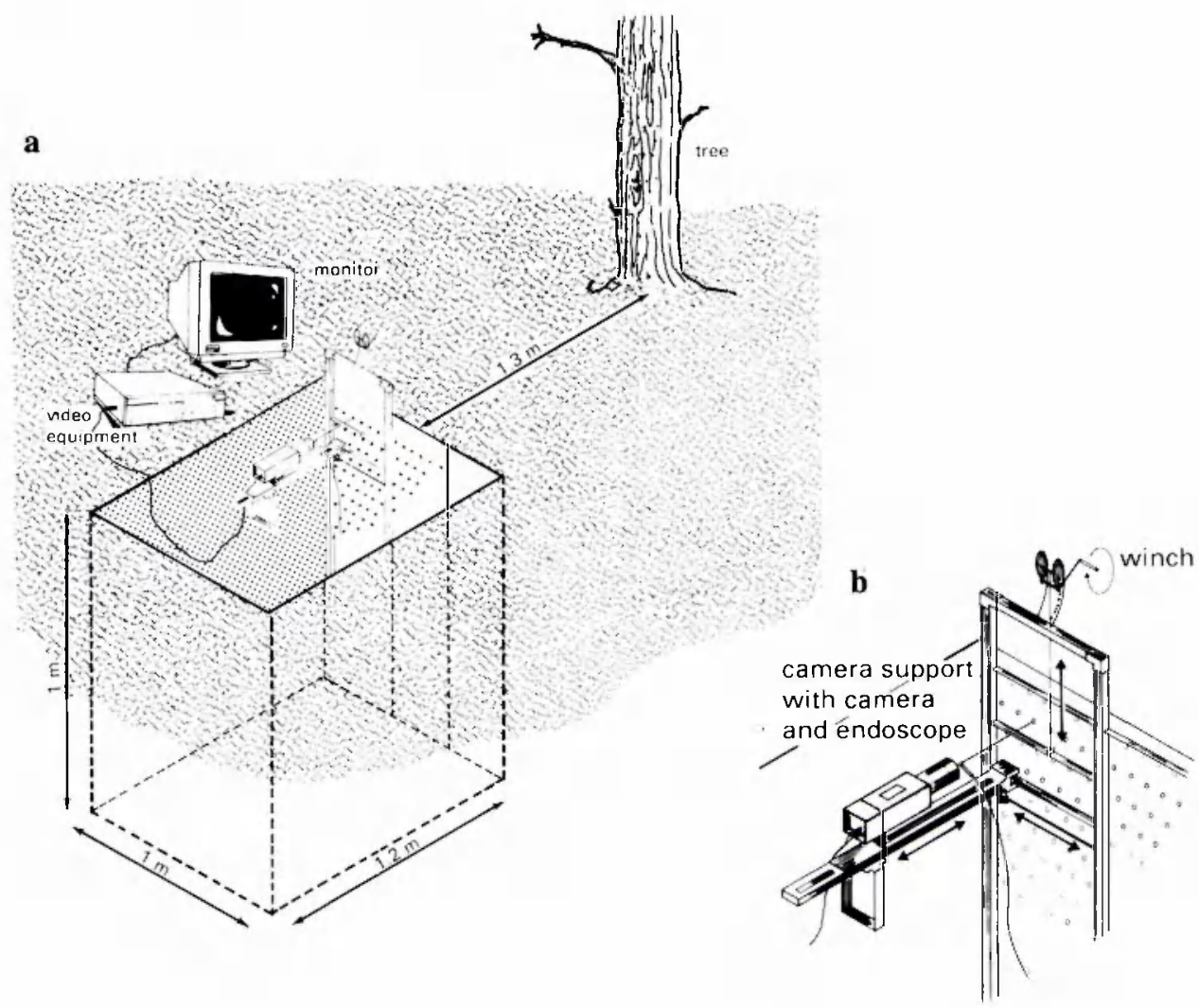

c

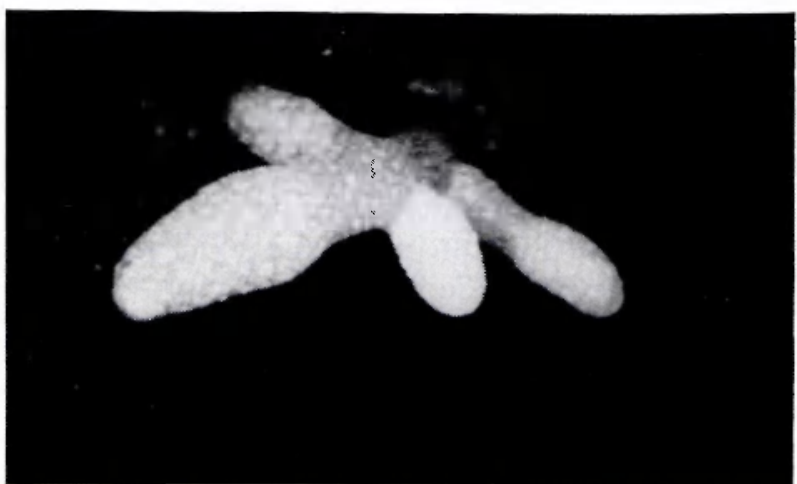

Fig. 1. Schematic illustration of (a) perforon root cellar with video equipment near a mature tree in a forest stand, (b) camera stand with endoscope and CCD video camera and (c) example of Russula ochroleuca mycorrhiza (diameter $1 \mathrm{~mm}$ ) as visible in the perforon root cellar during development (endoscope photograph by G. M. J. H. Ackermans). 
Soil water pressure heads (water potentials) were monitored twice daily on a nearby subplot with tensiometers at depths ranging from 10 to $200 \mathrm{~cm}$ (Burt, 1978). Soil water contents at 50 to $150 \mathrm{~cm}$ depth were measured with the neutron scattering technique (Gardner \& Kirkham, 1952) in three access tubes per site. The soil water contents of the upper $70 \mathrm{~cm}$ of the soil were measured weekly by Time Domain Reflectometry (Topp et al., 1980). To obtain a continuous time series of soil water pressure heads and water contents, the SWIF model (Soil Water In Forested ecosystems; Tiktak et al., 1990) was calibrated with data on water contents and pressure heads. However, because tensiometer readings are not accurate when the soil is dry, preference was given to the data on water contents.

Rainfall was measured continuously in clearings near the ACIFORN stands. Soil temperature was continuously measured with diodes. The air temperature was continuously measured above the canopy.

\section{Calculation of belowground carbon allocation}

To estimate the amount of carbohydrates needed for the root system to perform as observed (see also Olsthoorn, 1991), we assumed that:

- The fine root biomass found in the corer sampling in early summer 1987 and 1988 (Olsthoorn, 1991) was at its maximum level at both sites. Both preceding winters were very mild and springs were moist, so high fine root mortality in that period is unlikely.

- In both stands the annual production of fine roots is equal to the maximum fine root biomass in early summer (Kurz \& Kimmins, 1987a).

- Coarse root growth can be estimated with the allometric relation developed by Kuiper \& Coutts (1991) using diameter increment of the stems, as presented by Olsthoorn (1991).

- $50 \%$ of the biomass of the coarse roots consists of heartwood, with no respiratory demands (Böttcher \& Liese, 1975).

- It is justifiable to exclude respiration by mycorrhizal root tips from the calculation of carbon allocation, because the frequency of mycorrhizal root tips on the ACIFORN sites was below $10 \%$ (Jansen \& de Nie, 1988).

Our calculations of growth and maintenance respiration with Equation 1 were based on parameters used in a simulation model of Douglas-fir growth developed by Mohren (1987). The relative maintenance respiration depends on the nitrogen and mineral content of the biomass, according to the following equation (Penning de Vries, 1975; de Wit et al., 1978):

$$
M=0.25 \times F_{\mathrm{N}}+0.08 \times F_{\mathrm{M}} \quad\left(\text { at } 25^{\circ} \mathrm{C}\right)
$$

where:

$M$ is respiratory demand in $\mathrm{g} \mathrm{CH}_{2} \mathrm{O} \mathrm{g}^{-1} \mathrm{~d}^{-1}$

$F_{\mathrm{N}}$ is nitrogen fraction of the dry matter

$F_{\mathrm{M}}$ is mineral fraction of the dry matter. 
The average nitrogen fraction of the fine roots from both sites in the 1988 sampling programme was 0.013 ; the average mineral fraction was 0.006 . Assuming an aboveground growing season of 200 days at $15^{\circ} \mathrm{C}$ with a $\mathrm{Q}_{10}$ of 2 (if the temperature is $10{ }^{\circ} \mathrm{C}$ lower, the relative maintenance respiration is halved) results in the yearly maintenance respiration $\left(M_{\mathrm{fr}}\right)$ for fine roots being $0.38 \mathrm{~g} \mathrm{CH}_{2} \mathrm{O} \mathrm{g}^{-1} \mathrm{yr}^{-1}$. The respiration characteristics for the maintenance of the living coarse root biomass $\left(M_{\mathrm{cr}}\right)$ are taken the same as those calculated by Mohren (1987) with Equation 2 for the sapwood in the stem, with very small nitrogen and mineral fractions, resulting in $0.021 \mathrm{~g} \mathrm{CH}_{2} \mathrm{O} \mathrm{g}^{-1} \mathrm{yr}^{-1}$ for coarse root sapwood in a 200 day season.

The carbohydrates actually transported to the root system were derived from the estimated annual growth of fine and coarse roots using a conversion efficiency $(G)$ of $0.65 \mathrm{~g}$ of dry matter produced per $\mathrm{g}$ carbohydrates (from Mohren, 1987, based on Penning de Vries \& van Laar, 1982).

\section{Results}

\section{Soil moisture and soil temperature}

Figure 2 presents data on rain and soil water pressure heads for 1988 and 1989. In 1988 , only a few short rain-free periods occurred. In 1989 there was a dry period in May and June, followed by other dry periods, interrupted by some heavy showers. Kootwijk and Speuld are $10 \mathrm{~km}$ apart and have the same rainfall pattern. This was reflected in the pattern of the soil water pressure heads in both years. In Kootwijk the soil water pressure heads were less and decreased earlier in spring than Speuld in both years, because the soil had a smaller water holding capacity. In Speuld the water pressure heads rarely fell below -0.1 MPa (pF 3), even in 1989. In Kootwijk the soil at a depth of $80 \mathrm{~cm}$ was relatively dry for long periods, especially in 1989 . In the upper $50 \mathrm{~cm}$ of the soil, soil water pressure heads in Kootwijk were as low as $-0.1 \mathrm{MPa}(\mathrm{pF}$ 3) in May 1989, whereas in Speuld this value was not reached until 15 July in 1989. Because of heavy showers during the summer of 1989 the water pressure heads at $15 \mathrm{~cm}$ depth were very variable. The water pressure heads at greater depth showed a more steady pattern.

Figure 3 presents air temperature for Speuld and soil temperature for Kootwijk. The winters were mild for the Netherlands; hardly any frost occurred and the soil was never frozen.

\section{Periodicity of root growth}

The individual trees varied little in growth behaviour. As the patterns in the active growth period were comparable, the results of the individual perforons for one site were combined to give a general impression of the interaction with soil conditions. The numbers of mycorrhizal, brown and white root tips in the winter period were estimated from observations in only one perforon per site. The number of white root tips is used as an indication of the periodicity of root growth, but the number of root tips cannot be extrapolated to a hectare, because the physical conditions for root growth are different from soil and the soil volume sampled was small. 

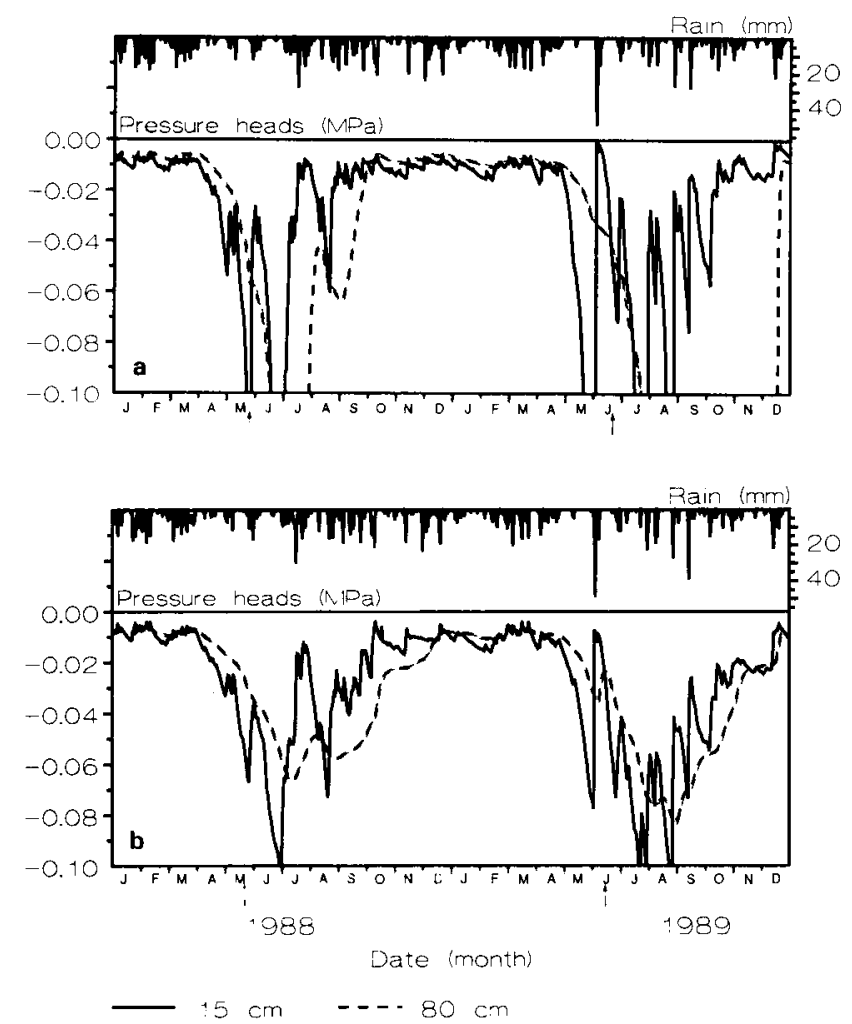

Fig. 2. Amounts of rain and estimates of soil water pressure heads during 1988 and 1989 for (a) Kootwijk and (b) Speuld. The estimates of soil water pressure heads are calculated with the simulation model SWIF, calibrated with tensiometer and neutron probe measurements (Tiktak et al., 1990). Arrows indicate root corer sampling date (Olsthoorn, 1991).

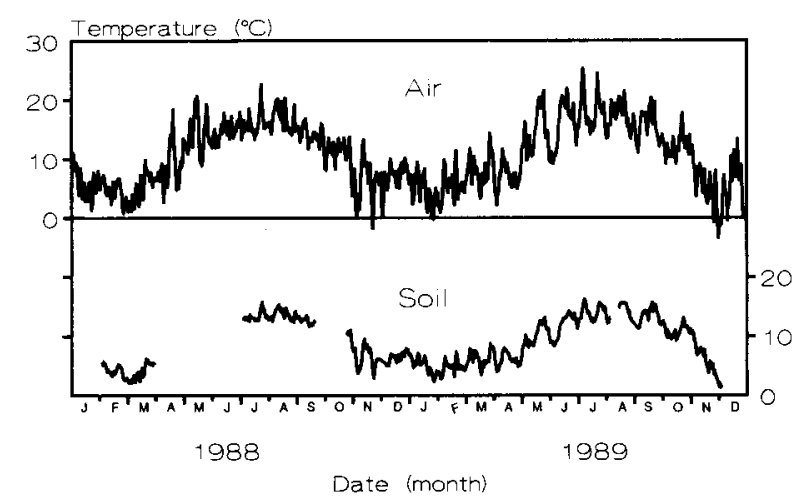

Fig. 3. Air temperatures above the forest canopy (Speuld) and soil temperatures at $15 \mathrm{~cm}$ depth (Kootwijk) during 1988 and 1989. 
A. F. M. OLSTHOORN AND A. TIKTAK
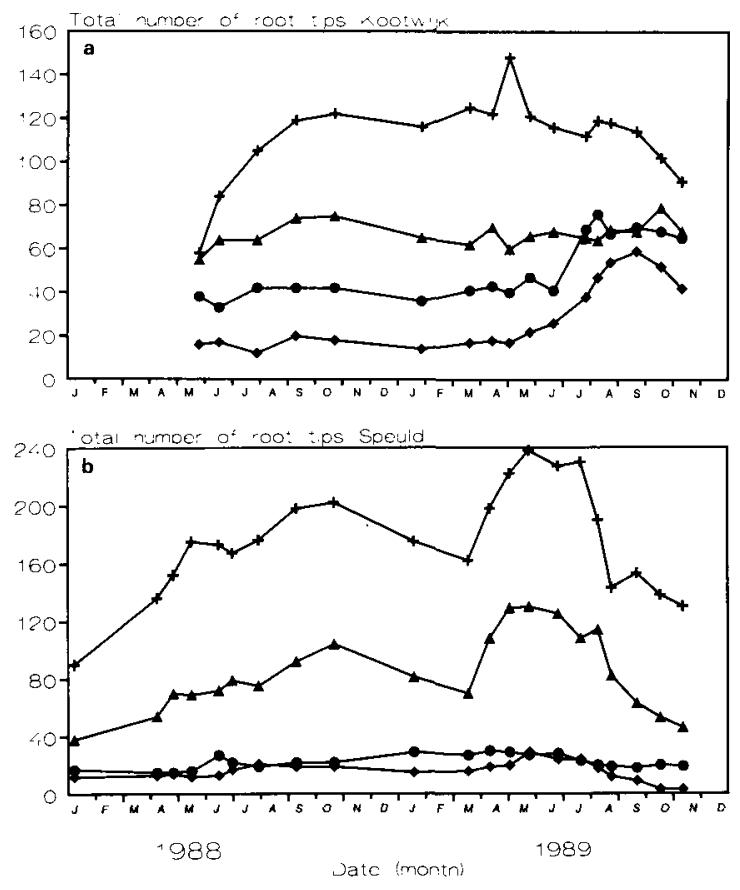

$\longrightarrow 0.20 \rightarrow 20.40 \rightarrow 40.60 \rightarrow 60.85$
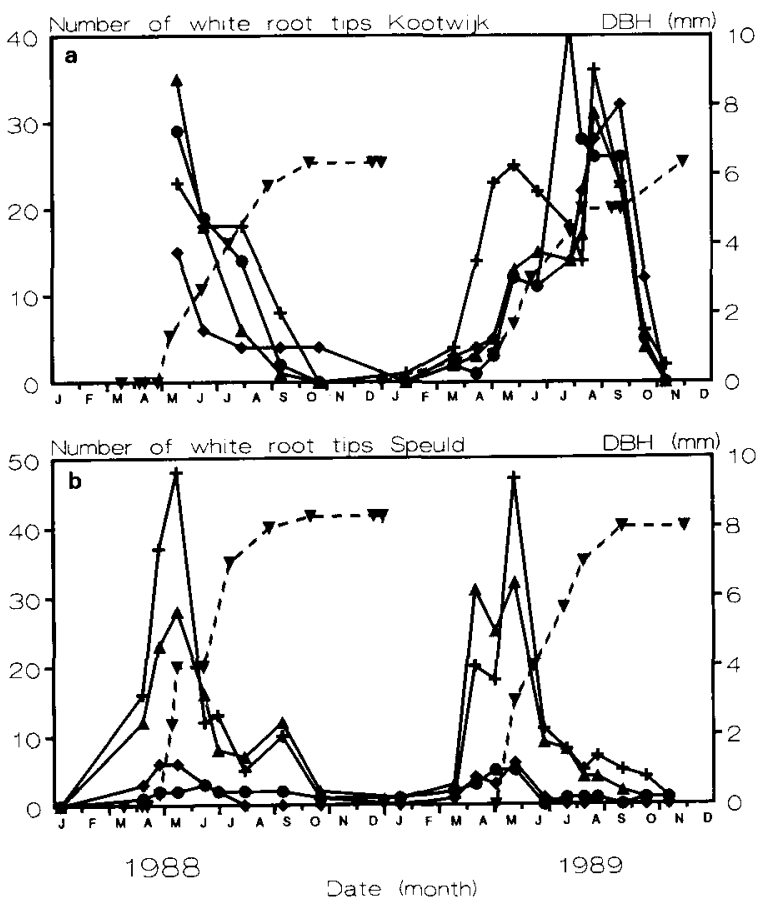

$\rightarrow 0-20 \rightarrow 20-40 \rightarrow 40-60$
Fig. 4. Total number of visible living root tips (mycorrhizal and non-mycorrhizal white and brown root tips) of Douglas-fir in three perforon root cellars during 1988 and 1989 in (a) Kootwijk and (b) Speuld (legend: depth indicated in $\mathrm{cm}$ ).

Fig. 5. Number of visible white root tips of Douglas-fir in three perforon root cellars and average diameter increment at breast height (DBH) of the three observed trees (cumulative per year) during 1988 and 1989 per soil layer in (a) Kootwijk and (b) Speuld (legend: depth indicated in $\mathrm{cm}$; dashed line is DBH increment). 

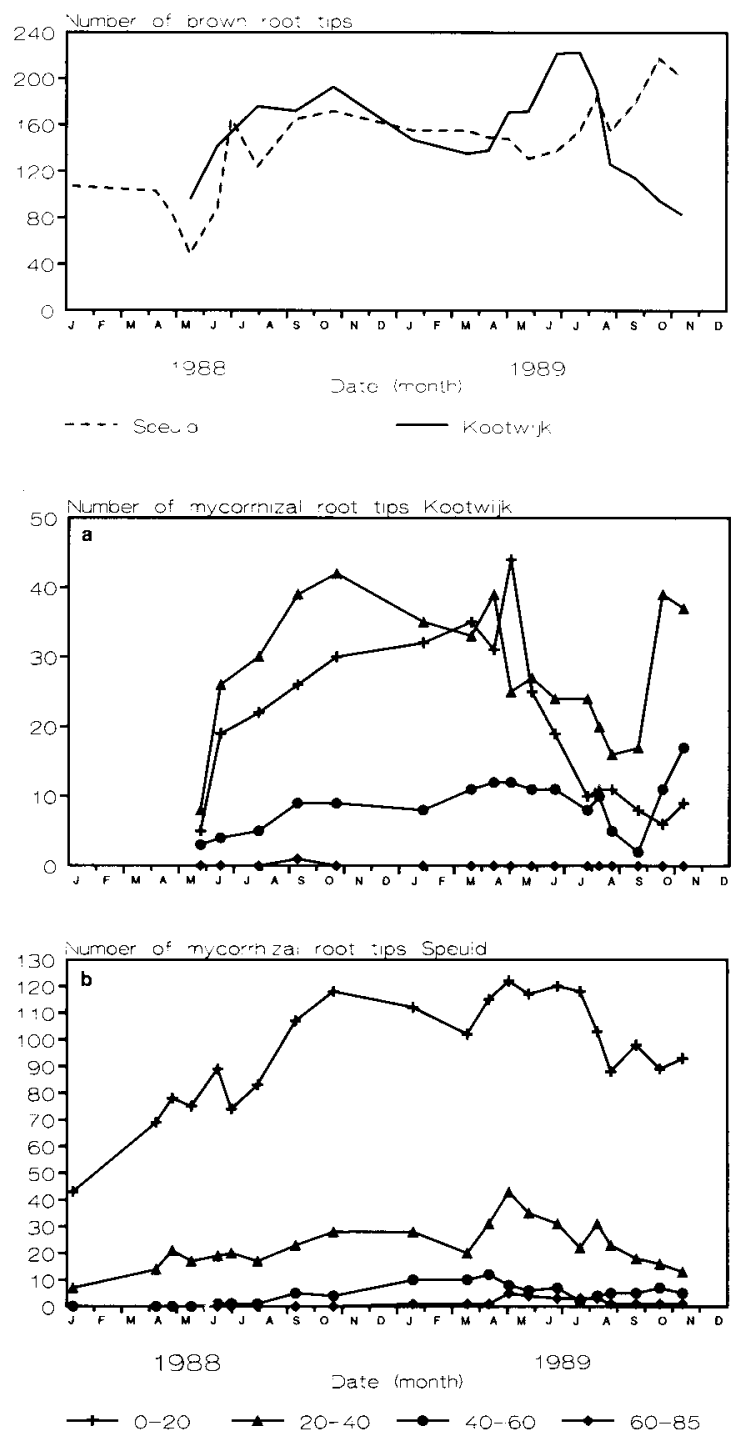

Fig. 6. Number of visible brown non-mycorrhizal root tips of Douglas-fir in three perforon root cellars during 1988 and 1989 in Kootwijk and Speuld (legend: depth indicated in $\mathrm{cm}$ ).

Fig. 7. Number of visible mycorrhizal root tips of Douglas-fir in three perforon root cellars during 1988 and 1989 in (a) Kootwijk and (b) Speuld (legend: depth indicated in $\mathrm{cm}$ ).

Figure 4 shows the total number of visible living root tips per soil layer of $20 \mathrm{~cm}$. At both sites the root tips were most numerous in the topsoil, in accordance with the vertical distribution of fine root density observed in root core samples (Olsthoorn, 1991). In spring the total number increased somewhat and in Speuld the number varied, especially in 1989. In the late summer of 1989 the total number of root tips in Kootwijk increased in the two deepest soil layers, but there was a decrease in the two uppermost soil layers in Speuld in that period. In autumn, numbers declined in both sites at all depths.

Figure 5 shows that the occurrence of white root tips was almost completely re- 
stricted to the period between the beginning of April and the end of September, with hardly any white root tips between October and March, while soil temperature was over $5{ }^{\circ} \mathrm{C}$ for much of the winter season (Figure 3). The root tips resumed growth fairly late in spring. The stem diameter growth started later in spring, associated with budbreak (May). In 1988 the white root tips at both sites were especially numerous in late spring, when budbreak occurred, and declined slowly toward the autumn. In 1989, the pattern in Speuld was nearly the same as in 1988, but in Kootwijk the pattern in both years was very different: there were relatively few white root tips in spring 1989 , but many white root tips at all depths during the whole summer. Furthermore, in Kootwijk the number of white root tips in the lowest soil layer declined the latest. In Speuld the number of white root tips showed the same pattern in all soil layers.

In Speuld the development of the stem diameter increment in 1989 was the same as in 1988. In Kootwijk the diameter increment was interrupted at the end of the summer of 1989, possibly because of low water pressure heads in the soil.

In periods with many white root tips there were usually few brown root tips, but the numbers increased later (Figure 6). In Speuld there was an increase in the springs of 1988 and 1989, as there was in Kootwijk in 1988. But in spring 1989 there was relatively little growth in Kootwijk (Figure 5) and therefore the number of brown root tips did not start to increase until summer and then mainly in the two deepest soil layers (see Figure 4). In the summer of 1989, there was a decrease in the number of brown root tips in Speuld when there was little root growth activity, and many roots died in the dry soil. The decrease was observed in the two uppermost soil layers (see Figure 4).

The dynamics in the numbers of mycorrhizae are shown in Figure 7. Some of the mycorrhizae may have been growing at the time of observation; this is not detectable from these data. The longitudinal growth of the mycorrhizal root tips was much slower than that of non-mycorrhizal white root tips. The fluctuation in number of mycorrhizae is caused either by mycorrhizal roots growing into or out of the channels, or by the death of visible mycorrhizae. Each spring, longitudinal growth of mycorrhizae could be seen in the development of new 'sprouts' at the mycorrhizal root tips (Figure 1c). Not only the absolute number of mycorrhizae, but also the frequency of mycorrhizal root tips decreased with depth, as can be seen from Figures 4 and 7. However, mycorrhizae were found at all observed depths. In Kootwijk the numbers of mycorrhizal root tips started to increase from the spring of 1988 (Figure 7). In the two uppermost soil layers the number of mycorrhizal root tips remained fairly constant until the summer of 1989 when they declined drastically, before increasing rapidly again in the autumn. In the two deeper soil layers there were no changes in the number of mycorrhizal root tips. The results from Speuld suggest that during the winter, roots with a mycorrhizal mantle can continue to grow at lower temperatures than roots without such a fungal mantle. In the mild winter of ' $87 /$ ' 88 the number of brown root tips remained the same (Figure 6), but the number of mycorrhizal root tips rose as new tips continued to grow into the channels. During the summer of 1989 the numbers of mycorrhizae in Speuld declined more slowly than the numbers of brown root tips. 
Table 1. Estimated belowground carbon allocation in both ACIFORN Douglas-fir stands in 1988. Fine and coarse root biomass data from Olsthoorn (1991). Symbols, calculation methods and assumptions are explained in the text.

$\begin{array}{lll}\begin{array}{l}\text { Coarse roots } \\ \text { (sapwood) }\end{array} & \text { Fine roots } & \text { Total }\end{array}$

Kootwijk

\begin{tabular}{|c|c|c|c|}
\hline $\begin{array}{l}\text { Biomass }\left(\mathrm{tha}^{-1}\right) \\
\text { Growth }\left(\mathrm{t} \mathrm{ha}^{-1} \mathrm{yr}^{-1}\right) \\
\text { Requirements for: }\end{array}$ & $\begin{aligned} & 12.4(\left.=W_{\mathrm{cr}}\right) \\
& 1.0\left(=P_{\mathrm{cr}}\right)\end{aligned}$ & $\begin{array}{l}4.3\left(=W_{\mathrm{ft}}\right) \\
4.3\left(=P_{\mathrm{fr}}\right)\end{array}$ & \\
\hline - maintenance respiration ${ }^{1}$ & 0.3 & 1.6 & 1.9 \\
\hline - growth ${ }^{1}$ & 1.5 & 6.6 & 8.1 \\
\hline Total carbon requirements ${ }^{1}$ & 1.8 & 8.2 & $10.0\left(=C_{\mathrm{b}}\right)$ \\
\hline
\end{tabular}

Speuld

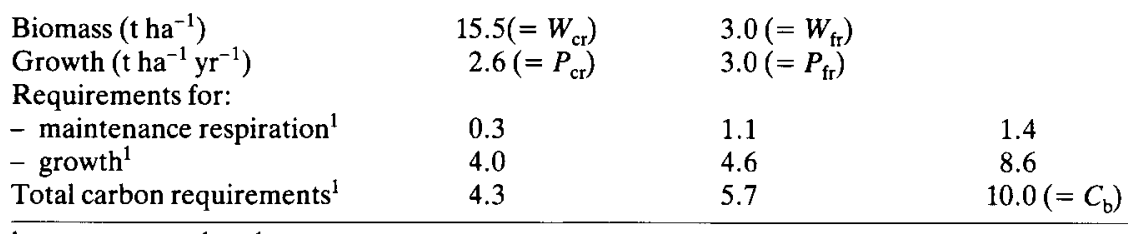

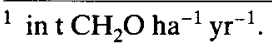

\section{Estimation of belowground carbon allocation}

The calculations in Table 1 were made only for 1988, using Equation 1, in order to give an impression of the carbon allocation to be belowground part of the forest stand, based on data from Olsthoorn (1991). Because of the greater nitrogen and mineral content, the estimated maintenance respiration of fine roots in both sites was greater than that of the coarse root biomass, even though their dry weight was much less. In 1988 the total amount of assimilates needed for the performance of the root system in both Kootwijk and Speuld was just over 10 ton $\mathrm{CH}_{2} \mathrm{O} \mathrm{ha}^{-1} \mathrm{yr}^{-1}$. However, in Kootwijk the total requirements of the fine roots $\left(8.2\right.$ ton $\mathrm{CH}_{2} \mathrm{O}$ $\mathrm{ha}^{-1} \mathrm{yr}^{-1}$ ) were greater than in Speuld (5.8 ton $\mathrm{CH}_{2} \mathrm{O} \mathrm{ha} \mathrm{hr}^{-1}$ ), and the total requirements of the coarse roots were less. The total requirements for growth of the root system in Kootwijk and in Speuld were 4.3 and 5.9 times more, respectively, than total maintenance respiration.

\section{Discussion}

Fine root mortality and soil water pressure heads

In the perforon root cellars it was observed that during the summer 1989 sometimes white root tips had already died within four weeks. The 1989 root sampling programme (Olsthoorn, 1991), revealed that early in the summer of 1989 the fine root 
biomass in Kootwijk was only $24 \%$ of the fine root biomass in the same period in 1987 and 1988; the corresponding value for Speuld was $34 \%$. Kurz \& Kimmins (1987a) also found less fine root biomass after a dry period in summer.

Kuhns \& Gjerstad (1988) state that the transport of assimilates to the root system decreases in dry periods. This may cause a temporary reduction in root growth. Extreme drought can cause fine roots to die, as is described in Parker \& Pallardy (1988), Marshall (1986) and Deans (1979). Parker \& Pallardy (1988) state that roots lose relatively more water at the wilting point than leaves, because of the collapse of the cortical tissue. However, the roots do not always die under these conditions. Drought can greatly reduce the biomass of fine roots when insufficient carbohydrates (starch and sugars) are available in those roots (Marshall, 1986). Krueger \& Trappe (1967) found that starch and sugar concentrations in fine roots of Douglas-fir seedlings peaked just before budbreak and were at minimum in June. Singh \& Srivastava (1986) also found a declining carbohydrate content just after budbreak. This would imply that fine roots are especially sensitive to water shortage in early summer. Deans (1979) found that in some situations fine roots of spruce die when soil $\mathrm{pF}$ values are less than 3 .

Based on the assumption that it is possible to recognize dead roots in a corer sample as soon as one week after their death, it was possible to relate the amount of fine roots in both years to the soil water potential conditions one week before sampling. In Figure 2 the date of the root corer sampling is indicated for both sites in 1988 and 1989. In 1988 the soil water pressure heads in both sites did not decrease below $-0.05 \mathrm{MPa}(=\mathrm{pF} 2.7)$ in that period. In 1989 however, there was a period in both Speuld and Kootwijk during which soil water pressure heads were below -0.08 $\mathrm{MPa}(=\mathrm{pF} 2.9)$ at $15 \mathrm{~cm}$ depth. This means that in sandy soils some of the fine roots had already died at soil water pressure heads of around $-0.08 \mathrm{MPa}(=\mathrm{pF} 2.9)$. At $80 \mathrm{~cm}$ depth the soil water pressure heads at Speuld were still more than $-0.03 \mathrm{MPa}$ $(=\mathrm{pF} 2.5)$ whereas in Kootwijk it was more than $-0.05 \mathrm{MPa}(=\mathrm{pF} 2.7)$ in that period.

If many roots in the topsoil die, the demand for uptake of water per unit of root length in the subsoil increases. According to de Willigen \& van Noordwijk (1987) this implies that the gradients of water content in the rhizosphere become steeper in a soil with a poor hydraulic conductance, as in Kootwijk. At rapid water uptake rates, roots in the subsoil must have died at water pressure heads of $-0.03 \mathrm{MPa}$ (= $\mathrm{pF} 2.5$ ) in the bulk soil, because water pressure heads in Speuld at $80 \mathrm{~cm}$ depth were more than that just before sampling in 1989 (Figure 2). Water pressure heads in the rhizosphere were not determined. The water pressure heads at the root surface may fall to a lethal level even though the bulk soil still contains a reasonable amount of water. This situation associated with differing physical soil conditions could explain the large differences that are found in literature for soil moisture conditions that result in fine root death (Deans, 1979; Parker \& Pallardy, 1988). Both transpiration and soil hydraulic conductivity influence the difference between water pressure heads at the root surface and in the bulk soil (de Willigen \& van Noordwijk, 1987). Therefore, the values that were found for these sites in the early part of the growing season may not be valid in other conditions. 


\section{Periodicity of root growth}

The soil temperatures at $15 \mathrm{~cm}$ depth in winter were around $5{ }^{\circ} \mathrm{C}$, and the fine root growth activity was limited, though Kuhns et al. (1985) found that root growth can occur when the soil temperature is above $4{ }^{\circ} \mathrm{C}$ and Teskey \& Hinckley (1981) found root growth all year around. Root growth was not intensively monitored during the winter periods, but occasionally a white root tip was found. Krueger \& Trappe (1967) also found occasional white root tips in Douglas-fir seedlings in a nursery in winter, even in periods with frost. They found for Douglas-fir seedlings in Oregon, USA, that many active root tips occurred just before budbreak, few during shoot elongation, but thereafter numbers slowly increased to moderate levels until mid autumn. Ladefoged (1939) and Lyr \& Hofmann (1967) found that root growth activity in most tree species peaked in June or July. Santantonio \& Hermann (1985) found a less distinct seasonal pattern in the number of new root tips of Douglas-fir in Oregon. They found that the number of new root tips fluctuated much more on the dry site than on the wetter sites. This agrees with our findings in Kootwijk (dry) and Speuld (wet). On drier sites fine roots take a greater part of the carbon budget of the stand (Table 1).

During the actual period of longitudinal growth of the root tips in Kootwijk in the summer of 1989 , the mycorrhizal fungus did not inoculate the roots, but apparently the fresh root tips were easy to colonize as soon as the longitudinal growth stopped, as can be seen in the quick increase in number of mycorrhizae in Kootwijk in the autumn of 1989 (Figure 7).

We did not measure the average turnover of fine roots, but the intense root tip activity in 1989 (especially in Kootwijk after the dry periods) suggests it was greater in 1989 than in 1988. However, in 1989 the average stem increment of the trees observed at both sites did not decrease as a result of the necessarily greater demand for assimilates in the root system.

\section{Belowground carbon allocation}

Few data are available on heartwood formation in coarse roots. Böttcher \& Liese (1975) presented data for Larch, where a substantial part of the coarse roots consists of heartwood. In our calculations (Table 1), the carbon allocation patterns will not change drastically if the assumption on sapwood: heartwood ratio is changed.

Chakravarty \& Chatarpaul (1990) have shown that the shoot:root ratios of seedlings of Larix laricina decreased as mycorrhizal infection increased. Baas et al. (1989) found that in fungal tissue of vesicular-arbuscular mycorrhizal plants the respiration rates were faster than in sterile root tissue, and more energy was needed to take up nutrients. Mycorrhizae thus play a role in the carbon allocation patterns and the functional equilibrium in plants. Considering the few mycorrhizae in our stand (Jansen \& de Nie, 1988) and the nature of our calculations, inclusion of fungal respiration would not make the results more accurate.

In the carbon allocation to the total root system the amount of carbohydrates needed for fine root growth is especially large. This means that the assumed annual 
fine root production strongly influences the estimate of the total belowground carbon allocation. It is difficult to measure fine root production in the field. Estimates are usually based on sampling with a root corer at intervals of one month. The production and mortality of fine roots is then calculated from differences in the amount of biomass and necromass in these samples. Singh et al. (1984) and Kurz \& Kimmins (1987b) have shown that this can cause over- or underestimation of the actual productivity.

Santantonio (1989) proposed using aboveground stand performance to calculate the total carbon allocation to the root system. In his approach, which is based on literature data, the percentage of the total primary production in a stand allocated to the root system depends on the amount allocated to the stem. This relation is estimated in a simple regression model, and it describes changes to the shoot:root ratio induced by site quality.

From the approach of Santantonio (1989) and calculations according to this principle with data from the ACIFORN Douglas-fir stands (results not shown), the conclusion is that the average annual turnover of fine roots in this study does indeed agree with our assumption that the annual production of fine roots is equal to the fine root biomass in early summer.

Usually, there are fewer fine roots at more productive sites (Kurz \& Kimmins, 1987a; Vogt et al., 1987; Walters \& Reich, 1989). Irrigation and fertilization also result in fewer fine roots (Linder \& Axelsson, 1982). This conclusion could also be drawn in these two study sites (Olsthoorn, 1991). This means that the total carbon allocation to the fine roots in Kootwijk is larger than in Speuld, even if there is some uncertainty in our estimation of the annual production of fine roots. The carbon allocation to the coarse roots shows the opposite picture: smaller in Kootwijk than in Speuld, because of its relation to aboveground growth rates. This is to be expected, because the coarse root system has the same function as the stem: support and transport of solutes, whereas the fine roots serve as an interface for the uptake of water and nutrients.

According to Brouwer (1983), the shoot:root ratio in herbaceous plants is fairly stable if the growing conditions remain constant. In forest soils in the Netherlands, however, nitrogen availability has changed because of atmospheric deposition and instead of being limiting it is now excessive (van Breemen et al., 1982; Mohren et al., 1986; Hüttl, 1990; Kazda, 1990; van den Burg, 1990). This means that shoot growth is stimulated, whereas the allocation to the fine roots is decreased (Linder \& Axelsson, 1982). As a result of nitrogen deposition, the coarse root biomass has increased concomitantly with stem biomass. However, because the fine root biomass is the major destination for the carbohydrates, it is concluded that nowadays the carbon allocation to the root system is less than it was before nitrogen availability increased because of intensified factory farming in the Netherlands (van den Burg $\&$ Kiewiet, 1989). This partially explains why nitrogen fertilization results in increases in aboveground tree growth.

When fine root biomass decreases, the fine root density also decreases. As a result, functional equilibrium of the shoot:root ratio (the ratio of needle biomass to fine root biomass) shifts considerably. The stimulated aboveground growth does 
have a drawback: the capacity for uptake is reduced whereas the demand for water and nutrients of the aboveground biomass has increased. This may enhance the stands susceptibility to drought and deficiencies of nutrients other than nitrogen.

\section{Acknowledgements}

This project was supported by the Dutch Priority Programme on Acidification. The perforon root cellars were installed with help from E. A. P. de Bruijn, J. Post and J. Laurens. A. W. M. Vermetten provided air temperature data. 'De Dorschkamp' Research institute of Forestry and Urban Ecology offered facilities during the preparation of this paper.

G. M. J. Mohren, W. G. Keltjens, R. Rabbinge and G. F. Weetman deserve special mention for valuable comments on the manuscript. Figures were prepared by J. Tahitu.

\section{References}

Baas, R., A. van der Werf, \& H. Lambers, 1989. Root respiration and growth in Plantago major as affected by VA mycorrhizal infection. Plant Physiology 91: 227-232.

Bosch, A. L., 1984. A new root observation method: the perforated soil system. Acta Oecologica/Oecologia Plantarum 5: 61-74.

Böttcher, P. \& W. Liese, 1975. Zur Verkernung des Wurzelholzes von Fichte und Lärche. Forstwissenschaftliches Centralblatt 94: 152-160.

Breemen, N. van, P. A. Burrough, E. J. Velthorst, H. F. van Dobben, T. de Wit, T. B. Ridder, \& H. F. R. Reijnders, 1982. Soil acidification from atmospheric ammonium sulphate in forest canopy through fall. Nature 299: 548-550.

Brouwer, R., 1983. Functional equilibrium: sense or nonsense? Netherlands Journal of Agricultural Science 31: 335-348.

Burg, J. van den, 1990. Stickstoff- und Säuredeposition und die Nährstoffversorgung niederländischer Wälder auf pleistozänen Sandböden. Forst und Holz 45: 597-605.

Burg, J. van den \& H. P. Kiewiet, 1989. Cattle density and foliar composition of Scots pine, Douglas-fir and Corsican pine in the 'Peel' area in the Netherlands between 1956 and 1988. (In Dutch.) Report No 559, Research Institute for Forestry and Urban Ecology 'De Dorschkamp', Wageningen, Netherlands, $77 \mathrm{pp}$.

Burt, T. P., 1978. An automatic fluid-scanning switch tensiometer system. Technical Bulletin No 21, British Geometrical Research Group, 29 pp.

Chakravarty, P. \& L. Chatarpaul, 1990. Effecty of fertilization on seedling growth, ectomycorrhizal symbiosis, and nutrient uptake in Larix laricina. Canadian Journal of Forest Research 20: 245-248.

Deans, J. D., 1979. Fluctuations of the soil environment and fine root growth in a young Sitka spruce plantation. Plant and Soil 52: 195-208.

Evers, P., C. J. M. Konsten \& A. W. M. Vermetten, 1987. Acidification research on Douglas-fir forests in the Netherlands (ACIFORN project). In: P. Mathy (Ed.), Air pollution and ecosystems, p. 887. Reidel Publishing Company, Dordrecht.

Gardner, W. R. \& D. Kirkham, 1952. Determination of soil moisture by neutron scattering. Soil Science 78: 340-391.

Hüttl, R. F., 1990. Nutrient supply and fertilizer experiments in view of $\mathrm{N}$ saturation, Plant and Soil 128: 45-58.

Jansen, A. E. \& H. W. de Nie, 1988. Relations between mycorrhizas and fruitbodies of mycorrhizal fungi in Douglas-fir plantations in the Netherlands. Acta Botanica Neerlandica 37: 243-249.

Kazda, M., 1990. Indications of unbalanced nitrogen nutrition of Norway spruce stands. Plant and Soil 128: 97-101. 


\section{A. F. M. OLSTHOORN AND A. TIKTAK}

Krueger, K. W. \& J. M. Trappe, 1967. Food reserves and seasonal growth of Douglas-fir seedlings. Forest Science 13: 192-202.

Kuhns, M. R., H. E. Garret, R. O. Teskey, \& T. M. Hinckley, 1985. Root growth of black walnut trees related to soil temperature, soil water potential and leaf water potential. Forest Science 31: 617-629.

Kuhns, M. R. \& D. H. Gjerstad, 1988. Photosynthate allocation in loblolly pine (Pinus taeda) seedlings as affected by moisture stress. Canadian Journal of Forest Research 18: 285-291.

Kuiper, L. C. \& M. P. Coutts, 1991. Spatial disposition and extension of the structural root system of Douglas-fir. Forest Ecology and Management (in press).

Kurz, W. A. \& J. P. Kimmins, 1987a. The influence of site quality on tree resource allocation to fine roots and its effect on harvestable productivity of coastal Douglas-fir stands. Faculty of Forestry, University of British Columbia, Vancouver, Canada, FRDA Report No 034, 103 pp.

Kurz, W. A. \& J. P. Kimmins, 1987b. Analysis of some sources of error in methods used to determine fine root production in forest ecosystems: a stimulation approach. Canadian Journal of Forest Research 17: 909-912.

Ladefoged, K., 1939. Untersuchungen über die Periodocität im Ausbrauch und Längenwachstum der Wurzeln bei einigen unser gewöhnlichsten Waldbäume. Det Forstlige Forsøgsvaesen i Danmark 16: 1256.

Linder, S. \& B. Axelsson, 1982. Changes in carbon uptake and allocation patterns as a result of irrigation and fertilization in a young Pinus sylvestris stand. In: R. H. Waring (Ed.), Carbon uptake and allocation in subalpine ecosystems as a key to management, p 38-44. Forest Research Laboratory, Oregon State University, Corvallis, USA.

Lyr, H. \& G. Hoffmann, 1967. Growth rates and growth periodicity of tree roots. International Revue of Forestry Research 2: 181-206.

Marshall, J. D., 1986. Drought and shade interact to cause fine-root mortality in Douglas-fir seedlings. Plant and Soil 91: 51-60.

McClaugherty, C. A., J. D. Aber, \& J. M. Melillo, 1982. The role of fine roots in the organic matter and nitrogen budgets of two forested ecosystems. Ecology 63: 1481-1490.

Mohren, G. M. J., 1987. Simulation of forest growth, applied to Douglas-fir stands in the Netherlands. Doctoral Thesis, Wageningen Agricultural University, Wageningen, Netherlands, 184 pp.

Mohren, G. M. J., J. van den Burg \& F. W. Burger, 1986. Phosphorus deficiency induced by nitrogen input in Douglas-fir in the Netherlands. Plant and Soil 95: 191-200.

Olsthoorn, A. F. M., 1991. Fine root density and root biomass of two Douglas-fir stands on sandy soils in the Netherlands. 1. Root biomass in early summer. Netherlands Journal of Agricultural Science 39: 49. 60.

Parker, W. C. \& S. G. Pallardy, 1988. Leaf and root osmotic adjustment in drought-stressed Quercus alba, $Q$. macrocarpa and $Q$. stellata seedlings. Canadian Journal of Forest Research 18: 1-5.

Penning de Vries, F. W. T., 1975. The cost of maintenance processes in plant cells. Annals of Botany 39: 77-92.

Penning de Vries, F. W. T. \& H. H. van Laar, 1982. Simulation of growth processes and the model BACROS. In: F. W. T. Penning de Vries \& H. H. van Laar (Eds.). Simulation of plant growth and crop production, p. 114-135. Simulation Monographs, Pudoc, Wageningen, Netherlands.

Santantonio, D. \& R. K. Hermann, 1985. Standing crop, production, and turnover of fine roots on dry, moderate, and wet sites of mature Douglas-fir in western Oregon. Annales des Sciences Forestières 42: 113-142.

Santantonio, D., 1989. Dry-matter partitioning and fine root production in forests - New approaches to a difficult problem. In: J. S. Pereira \& J. J. Landsberg (Eds.), Biomass production by fast-growing trees, p. 57-72. Kluwer Academic Publishers, Dordrecht, Netherlands.

Singh, K. P. \& S. K. Srivastava, 1986. Seasonal variation in the biomass and non-structural carbohydrate content of fine roots of Teak (Tectona grandis L.f) plantations in a dry tropical region. Tree Physiology 1: 31-36.

Teskey, R. O. \& T. M. Hinckley, 1981. Influence of temperature and water potential on root growth of white oak. Physiologia Plantarum 52: 363-369.

Tiktak, A., W. Bouten, \& M. Schaap, 1990. SWIF: A simulation model of soil water in forested ecosystems. Program documentation and example. Version 2.0. Report No 44, Laboratory of Physical Geography and Soil Science, University of Amsterdam, $69 \mathrm{pp}$. 


\section{ROOT DENSITY AND ROOT BIOMASS OF DOUGLAS-FIR. 2}

Topp, G. C., J. L. Davis, \& A. P. Annan, 1980. Electromagnetic determination of soil water content: measurement of coaxial transmission lines. Water Resource Research 16: 574-582.

Tweel, P. A. van den \& B. Schalk, 1981. The horizontally perforated soil system: a new root observation method. Plant and Soil 59: 163-165.

Vogt, K. A., D. J. Vogt, E. E. Moore, M. B. Fatuga, M. R. Redlin \& R. L. Edmonds, 1987. Conifer and angiosperm fine-root biomass in relation to stand age and site productivity in Douglas-fir forests. Journal of Ecology, United Kingdom 75: 857-870.

Walters, M. B. \& P. B. Reich, 1989. Response of Ulmus americana seedlings to varying nitrogen and water status. 1. Photosynthesis and growth. Tree Physiology 5: 159-172.

Whiteley, G. M. \& A. R. Dexter, 1984. The behaviour of roots encountering cracks in the soil. I. Experimental methods and results. Plant and Soil 77: 141-149.

Willigen, P. de \& M. van Noordwijk, 1987. Roots, plant production and nutrient use efficiency. Doctoral Thesis, Wageningen Agricultural University, Wageningen, Netherlands, $282 \mathrm{pp}$.

Wit, C. T. de et al., 1978. Simulation of assimilation, respiration and transpiration of crops. Simulation Monographs, Pudoc, Wageningen, Netherlands, $141 \mathrm{pp}$. 